\title{
SEJARAH BERDIRINYA PERGURUAN RAKYAT (VOLKSUNIVERSITEIT) 1928 DI JAKARTA
}

\author{
Putut Wisnu Kurniawan \\ Program Studi Pendidikan Sejarah STKIP PGRI Bandar Lampung \\ Email: pututbukan@gmail.com
}

\begin{abstract}
Abstrak
Penelitian ini bertujuan untuk mendeskripsikan dan menganalisis mengenai sejarah berdirinya sekolah Perguruan Rakyat (Volksuniversiteit) di Jakarta 1928. Dalam penelitian ini permasalahan yang akan di bahas yaitu latar belakang sejarah berdirinya Perguruan Rakyat. Penelitian ini menggunakan metode sejarah kritis yang terdiri dari lima langkah, yaitu: (1) Pemilihan Topik, langkah awal dalam sebuah penelitian untuk menentukan permasalahan yang akan dikaji (2) Heuristik, kegiatan menghimpun jejakjejak atau sumber-sumber sejarah, (3) Kritik Sumber, kegiatan meneliti jejak-jejak atau sumber-sumber sejarah yang telah dihimpun sehingga diperoleh sumber-sumber yang otentik dan terpercaya, (4) Interpretasi merupakan kegiatan analisis yang didapatkan dari sumber yang telah dikumpulkan dan diverifikasi, (5) Historiografi merupakan kegiatan penyampaian sintesis dari penelitian yang ditulis secara kronologis. Hasil yang diperoleh dalam penetian ini adalah pertama Perguruan Rakyat didirikan atas dasar aplikasi dari Sumpah Pemuda dan dampak dari kebijakan politik etis. Munculnya nasionalisme merupakan sebagai acuan untuk memberikan pengertian ini kepada rakyat. Pendidikan adalah cara yang tepat untuk memberikan wawasan nasionalisme dan kebangsaan kepada rakyat. Tokoh-tokoh pendiri berasal dari beberapa alumni Perhimpunan Indonesia.
\end{abstract}

Kata Kunci: Sejarah, Perguruan Rakyat,Volksuniversiteit

\begin{abstract}
This research aims to description and analysis about the historical of Perguruan Rakyat School (Volksuniversiteit) in Jakarta (1928). The research of this special issue of the historical base of Perguruan Rakyat. This study in order to critical history method there are 5 steps such as: (1) Topic selection, this is first step in a research to certain issue will investigates, (2)Heuristic, this is step to assembling the historical sources, (3) Critical Source, it is the research of tracks or historical source which assembling so we found the authentic source and accurate, (4) Interpretation, this is the analysis of historical sources where it accociated and verificated, (5) Historigraphy, this is to telling of synthesis from chronological research. The results of this research are: First, Perguruan Rakyat builded the base of Sumpah Pemuda and the effect from ethicalpolicy decisions. Second, appear of nationalism is base to offering the understand for societies. Third, education is the effective step to offering the nationalism concept for societies. And Finally, the figures are the graduated of Perhimpunan Indonesia. Keyword: History, Perguruan Rakyat, Volksuniversiteit.
\end{abstract}

\section{PENDAHULUAN}

Kemerdekaan bangsa Indonesia dapat terwujud dikarenakan munculnya semangat nasionalisme yang membakar para pejuang bangsa. Berawal adanya keinginan kebebasan dari kaum penjajah, sehingga kebebasan merupakan idaman manusia yang harus direalisir sedapat mungkin, karena kita berada dalam situasi yang menyedihkan. Nasionalisme mulai tumbuh pada awal abad ke-20. Hal itu terlihat dengan didirikannya organisasi seperti Budi Utomo dan Indische Partij (Partai Hindia) yang merupakan organisasi bergerak dalam bidang politik.

Zaman pergerakan modern ditandai dengan munculnya berbagai 
organisasi-organisasi dan ideologi perlawanan pada masa itu. Sebut saja ideologi seperti Marxisme, Komunisme, Nasionalisme, Islamisme Marhaenisme sebagai ideologi yang banyak berpengaruh pada kaum pergerakan (Kuswono, 2016: 119). Sementara Organisasi yang muncul tidak hanya bergerak dalam bidang politik, tetapi juga dalam bidang pendidikan. Pertumbuhan pendidikan di Hindia Belanda melaju cepat. Bisa diketahui tahun 1922 Taman Siswa mulai berdiri. Ksatrian Institut di Bandung berdiri tahun 1923 serta tahun 1926 berdiri Indonesisch Nederlandsch School (INS) di Kayutanam yang didirikan oleh Mohammad Syafei tahun 1926.

Pendirian sekolah-sekolah itu merupakan bentuk perjuangan para tokoh intelektual untuk menularkan semagat nasionalisme. Sebagai salah satu contohnya adalah seorang tokoh dari Perhimpunan Indonesia yaitu Mr. Sunaryp dan Arnold Mononutu. Sebagai bukti akan adanya jiwa nasionalismenya, Mr. Sunario dan Arnold Mononutu mendirikan Volksuniversiteit pada tanggal 30 Agustus 1928. Sebelumnya Mr. Sunario dan Arnold Mononutu adalah tokoh Perhimpunan Indonesia yang masih aktif. Volksuniversiteit (Universitas Rakyat) merupakan sebuah badan yang kegiatannya meliputi ceramah-ceramah bagi para pemuda dan orang dewasa yang semuanya diselenggarakan pada siang dan sore hari. Kegiatan ini bersifat sederhana dengan mengedepankan semangat untuk mencerdaskan masyarakat pribumi pada waktu itu.

Dengan melihat perkembangan dan peluang yang ada maka tanggal 11 Desember 1928 Volksuniversiteit atas usul Moh. Yamin diganti menjadi Badan Persatuan Perguruan Rakyat. Nama ini biasa dikenal masyarakat dengan Perguruan Rakyat Malam atau PR Malam, karena diselenggarakan pada malam hari. Pada malam hari adalah waktu untuk mengurangi resiko mengingat masih ada kaum kolonial pada masa itu. Dengan dijiwai semangat Sumpah Pemuda terbentuk juga badan pengurus yang diketuai oleh Mr. Dr. Moh Nazief untuk menggerakkan roda keorganisasian Perguruan Rakyat.

Perguruan Rakyat merupakan sekolah dalam konsep kebangsaan. Hal ini dapat dilihat dalam sendi-sendi atau dasar-dasar Perguruan Rakyat dan sistem pengajaran yang diterapkan. Banyak masyarakat yang belum mengenal sekolah Perguruan Rakyat. Perjuangan yang dilakukan melalui pendidikan sama dengan yang dilakukan Ki Hajar Dewantara, Mohammad Syafei, Ahmad Dahlan dan sebagainya, akan tetapi perjuangan Mr. Sunaryo belum banyak diketahui. Selain itu peran beberapa tokoh jebolan Indonesische Vereniging atau Perhimpunan Indonesia 
pernah menjadi bagian dari sekolah ini. Artinya konsep nasionalisme yang dikembangkan dalam pendidikan. Oleh karena itu penulis tertarik mengambil tema tersebut.

Berhubungan dengan penulisan ini sejarah pendidikan di Indonesia tidak lepas berawal dari sebuah nasionalisme. Nasionalisme yang menjadi sebuah kekuatan untuk terlepas dari penjajahan khususnya pendidikan. Dalam buku yang ditulis oleh Koesalah dan Soesilo Toer berjudul Perguruan Rakyat 11 Desember 1928 dijelaskan makna penting sebuah nasionalisme hingga akhirnya muncul sebuah semangat untuk mengembangkan pendidikan sampai mendirikan sebuah yayasan yang dinamakan Perguruan Rakyat. Konsep kebangsaan oleh teori Ernest Renan dianggap pemikiran yang luar biasa yang menjadi pelecut semangat bagi masyarakat terutama pelajar bangsa kita yang sekolah di Belanda. Konsep itu salah satu pemicu para Mr. Sunario dan alumni Perhimpunan Indonesia lainnya tergerak dengan mendirikan yayasan Perguruan Rakyat.

Timbulnya bangsa yang mampu untuk mendirikan suatu negara kebangsaan sendiri berdasarkan "hak bangsa untuk menentukan nasib sendiri" (national self determination) tak lain adalah "keinginan untuk hidup bersama" (Le desir de virve d'etre ensemble) secara permanen (Koesalah dan Soesilo
1990: 143). Ini disebabkan oleh segolongan besar manusia telah dihayati bersama-sama segala rupa suka dan duka dalam waktu yang lampau, terutama duka (seperti dalam keadaan kita dijajah bangsa asing yang berlangsung berabad-abad lamanya itu).

Teori inilah yang menjadi pedoman pemuda-pemuda kita untuk perjuangan kita bersama semenjak dalam "Perhimpunan Indonesia" di negeri Belanda (Koesalah dan Soesilo 1990: 143). Dengan semangat itulah muncul nasionalisme dari jiwa pemuda Perhimpunan Indonesia dan ingin ditularkan kepada masyarakat Indonesia. Pelajar dari Belanda pulang dan segera merealisasikan konsepkonsep yang telah disepakati. Beberapa usaha dilakukan salah satunya adalah Sumpah Pemuda yang menjadi dasar politik untuk kemerdekaan bangsa. Artinya kemerdekaan utuh Indonesia dari Sabang sampai Merauke.

Beberapa alumni Perhimpunan Indonesia kemudian mendirikan Perguruan Rakyat yang dipimpin oleh Arnold Mononutu. Badan Persatuan Perguruan Rakyat resmi didirikan pada tanggal 11 Desember 1928. Perguruan ini mempunyai konsep kebangsaan dalam pengajarannya. Dalam buku yang berjudul Sejarah Perguruan Rakyat yang disusun oleh Koesalah Soebagyo Toer yang diterbitkan oleh Litbang Yayasan Perguruan Rakyat menjelaskan beberapa 
konsep perguruan rakyat. Konsep tersebut sering disebut konsep kebangsaan.

Konsep ini terdiri dari beberapa sendi, yaitu: sendi kebangsaan Indonesia, pendidikan jasmani, pembentukan watak, pendidikan pendirian dan pengetahuan yang berdasar kerakyatan, haluan hidup, pendidikan masyarakat. Sendi-sendi ini merupakan pembeda dari sekolah lain yang masih bersifat kedaerahan atau bersifat lokal. Perguruan Rakyat ini timbul tenggelam pada masa-masa tertentu. Pada masa penjajahan kolonial dan Jepang, Perguruan Rakyat mengalami tekanan yang cukup berat.

Dalam arsip naskah Kenangan Indah, karangan Mr. Sumanang tahun 1978, Perguruan Rakyat dan Masyarakat karangan Wilopo tahun 1978 menjelaskan Perguruan Rakyat mengalami jatuh bangun. Perguruan Rakyat harus berpindah tempat karena desakan Jepang dan hampir dibubarkan. Pada masa setelah proklamasi beberapa hambatan dalam sekolah ini juga bermunculan. Banyak pengurus dari perguruan rakyat yang terjun dalam dunia politik bahkan menjadi kabinet pemerintahan. Hal itu berdampak dengan kurang terkelolanya Perguruan Rakyat. Dengan semangat nasionalisme Perguruan Rakyat terus bertahan.

Dalam buku karangan Hussin (1976: 31) bahwa tujuan dan perkembangan pendidikan pada masa Belanda, pada masa Jepang dan pada masa kemerdekaan. Penulis menjelaskan adanya perbedaan antara keadaan dan tujuan pendidikan yang diadakan pada waktu itu. Pada masa pemerintahan Belanda secara singkat tujuan pendidikan Belanda adalah untuk memperoleh tenaga kerja murah dan adanya pembedaan kelas dalam pendidikan pemerintahan Hindia Belanda.

Suatu fakta menurut hasil komisi pendidikan Indonesia-Belanda (Hollansch Inlandsch Onderwijs Commissie) yang dibentuk tahun 19281929 menunjukkan bahwa 2\% dari orang Indonesia yang mendapat pendidikan barat dan lebih dari 83\% menjadi pekerja bayaran serta selebihnya menganggur (Hussin 1976: 30). Hampir sama dengan pendidikan pada masa Jepang tujuannya menyediakan tenaga kasar dan prajurit untuk membantu peperangan bagi kepentingan Jepang. Hal ini bisa dilihat dalam pelajar-pelajar diharuskan mengikuti latihan fisik, latihan militer dan indoktrinasi ketat serta mengembangkan pendidikan Jepang pada anak-anak bangsa.

\section{METODE PENELITIAN}

Metode penelitian sejarah merupakan alat dari ilmu sejarah untuk menyusun kisah sejarah berdasarkan jejak masa lampau sebagai sumbernya. 
Menurut Kuntowijoyo (2005: 91), tahapan penelitian sejarah mempunyai lima tahap yaitu pemilihan topik, heuristik, verifikasi, intepretasi dan penulisan. Pemilihan topik, merupakan sebuah langkah awal dalam sebuah penelitian untuk menentukan permasalahan yang akan dikaji. Penentuan topik ini harus dipilih berdasarkan kedekatan intelektual dan kedekatan emosional. Dua syarat tersebut penting karena akan berpengaruh pada aspek subjektif dan objektif, sebab seorang peneliti akan bekerja dengan baik apabila peneliti senang dangan topik yang ada dan mampu menyelesaikan penelitian.

Heuristik atau mengumpulkan sumber-sumber sejarah dilakukan penulis dengan mengunjungi beberapa perpustakaan yang mempunyai koleksi buku atau menyediakan bahan yang berkaitan dengan perkembangan Perguruan Rakyat. Perpustakaan yang menjadi tujuan penulis antara lain, adalah Perpustakaan Pramoedya Ananta Toer Anak Blora (PATABA) di Blora, Perpustakaan Kolese Ignatius Kota Baru Yogyakarta. penulis menemukan sumber primer yaitu Koleksi Arsip Yayasan Perguruan Rakyat. Peneliti akan melakukan wawancara dengan bapak Soesilo Toer selaku pengelola Perguruan Rakyat di Jakarta tahun 1990 sampai 2003.
Verifikasi (Kritik Sumber) merupakan kegiatan meneliti untuk menentukan validitas dan reabilitas sumber sejarah melalui kritik ekstern dan intern. Mencari kelemahan dan kelebihan dari data yang telah didapat dan memberikan solusi dalam penulisan sejarah. Kritik sumber adalah kegiatan meneliti untuk menentukan validitas dan reabilitas sumber sejarah melalui kritik ekstern dan intern.

Pada tahap interpretasi penulis berusaha menguraikan sumber dan mengaitkan fakta kemudian mengolah dan menganalisis dengan menggunakan pendekatan sehingga mempunyai arti dan bersifat logis. Penulis dapat menafsirkan fakta sejarah yang ditemukan dan telah melalui proses verifikasi sehingga dapat menghasilkan sebuah karya. Dalam tulisan ini penulis mencoba membangun pemahaman dan menangkap makna dari proses latar belakang bagaimana lahirnya perguruan rakyat hingga berkembang dengan perguruan dengan konsep kebangsaan. Historiografi atau penulisan sejarah, dalam hal ini penulis mengembangkan ide-ide hubungan antara fakta sehingga tulisan yang ditulis bisa bersifat objektif sesuai dengan fakta itu sendiri. Historiografi adalah tahapan akhir penulis untuk menyajikan fakta dalam bentuk tulisan dengan judul: "Sejarah Berdirinya Perguruan Rakyat (Volksuniversiteit) 1928 di Jakarta”. 
Penelitian ini menggunakan beberapa pendekatan, yaitu pendekatan politik dan sosiologi. Menurut Sartono Kartodirdjo (1993: 4), tinjauan politik adalah tinjauan yang mengarah pada struktur kekuasaan, jenis kepempinan, hirarki, sosial, pertetangan dan lain sebagainya. Pendekatan politis akan menyoroti tentang pengaruh yang timbul ketika ada sebuah tekanan dari pihak lain. Sebuah pendidikan bisa dijadikan sebuah politik untuk mempengaruhi sebuah pemikiran. Nasionalisme dan konsep kebangsaan sebagai alat untuk meningkatkan wacana kepada penduduk pribumi dan sebagai provokator untuk menetukan sikap kepada kaum penjajah. Pendidikan yang mempunyai konsep kebangsaan inilah yang menjadi senjata politik untuk memerangi kebodohan dan penjajahan.

Sejarah memerlukan pendekatan sosiologi untuk dapat menelaah berbagai peristiwa sejarah. Sosiologi juga berperan dalam dalam menjalankan aktivitas kolektif manusia di masa lampau. Melalui pendekatan sosiologi maka dapat dijelaskan keadaan masyarakat yang mendorong untuk bergerak membentuk sebuah sekolah yang kemudian dinamakan Perguruan Rakyat. Dari komunitas beberapa alumni dari Perhimpunan Indonesia yang mempunyai gagasan atau ide yang disesuaikan dengan realita keadaan pada saat itu.

HASIL DAN PEMBAHASAN

Sejarah Berdirinya Perguruan Rakyat (Volkuniversiteit) di Jakarta
Perkembangan pendidikan di Indonesia pada abad ke 19 tidak terlepas dari peran para pelajar/mahasiswa Indonesia yang belajar di Belanda yang tergabung dalam Perhimpunan Indonesia. Perhimpunan Indonesia merupakan sebuah himpunan pelajar Indonesia yang ada di Belanda. Perhimpunan ini sebelumnya bernama Indische Vereniging yang didirikan tahun 1908. Pada masa itu Indische Vereniging tidak mempunyai tujuan politik, akan tetapi mempunyai tujuan om de gemeenscapplijke belangen derIndiers in Nederland te behartigen, artinya hanya untuk memperhatikan kepentingan bersama dari penduduk Hindia Belanda yang ada di negeri Belanda. Selain itu perhimpunan ini merupakan pusat kegiatan sosial dan kebudayaan sebagai ajang bertukar pikiran tentang situasi tanah air. Indische Vereniging didirikan oleh Sutan Kasayangan dan R.M. Noto Suroto. Dalam perkembangannya Indische Vereniging menjelma menjadi perkumpulan baru yang mengutamakan masalah politik, sehingga pada tahun 1925 Indische Vereniging diganti nama menjadi Perhimpunan Indonesia. Dalam masa pengaruh Moh. Hatta organisasi ini menjadi berkembang dan mengarah pada politik radikal. Oleh karena itu Perhimpunan Indonesia bertujuan sebagai berikut. 
1. Menyadarkan para mahasiswa agar mempunyai komitmen yang bulat tentang persatuan dan kemerdekaan Indonesia dan sebagai elite intelektual harus bertanggungjawab untuk memimpin rakyat melawan penjajah.

2. Perhimpunan Indonesia harus membuka mata rakyat Belanda bahwa pemerintah kolonial sangat opresif dan meyakinkan rakyat Indonesia tentang kebenaran perjuangan kaum nasionalis.

3. Mengembangkan ideologi yang bebas dan kuat di luar pembatasanpembatasan Islam dan komunisme.

Pada tahun 1926 kelompok organisasi yang tergabung dalam Perhimpunan Indonesia masih tergolong sedikit. Namun, bagi para pemuda yang aktif di bidang politik ini mempunyai pengalaman hidup dan belajar di negeri Belanda mempunyai dampak yang mendalam. Di sana untuk pertama kalinya mereka dianggap sederajat dengan orang Eropa dalam masyarakat maupun dalam hukum. Selain tujuan di atas Perhimpunan Indonesia juga mempunyai empat pikiran pokok antara lain sebagai berikut.

1. Kesatuan nasional

yang mengesampingkan perbedaan berdasarkan daerah dan membentuk kesatuan aksi melawan Belanda serta menciptakan Negara kebangsaan Indonesia yang merdeka dan bersatu.

2. Solidaritas merupakan pertentangan kepentingan antara penjajah dan mempertajam konflik kulit putih dan sawo matang.

3. Non koperasi merupakan kemerdekaan bukanlah hadiah dari Belanda, tetapi harus direbut dengan mengandalkan kekuatan sendiri.

4. Swadaya merupakan mengandalkan kekuatan sendiri dengan mengembangkan struktur alternatif dalam kehidupan nasional, politik sosial, ekonomi, dan hukum yang sejajar dengan administrasi kolonial.

Aktivitas dari Perhimpunan Indonesia bukan hanya di Belanda dan Indonesia saja melainkan juga di dunia internasional. Para pelajar yang kembali ke Indonesia dituntut untuk menyebarkan propaganda supaya masyarakat Indonesia bisa menerima gagasan dari Perhimpunan Indonesia. Propaganda disebarkan di Indonesia oleh tokoh-tokoh seperti Budhyarto, Sartono, Sunario, Arnold Mononutu dan beberapa pelajar lainnya. Tekad bulat yang dimiliki Perhimpunan Indonesia juga terlihat dengan digantinya majalah Hindia Poetra menjadi Indonesia Merdeka.

Dalam majalah itu pernah dimuat tentang peran kaum intelektual bangsa. Di dalam majalah itu disebutkan 
"Terhadap organisasi harus kita hadapkan dengan organisasi, terhadap kekuasaan, kekuatan kita. Orang-orang Indonesia yang lulus dari sekolah tinggi harus bergabung pada massa yang berjuang. Sudah terlalu lama kaum intelektual menjauhkan diri dari rakyat dan makin keras terdengar cercaan dari tanah air bahwa kebanyakan dari sarjana yang pulang tidak memperdulikan nasib massa yang menderita"(Suwidi Tono, 2009: 107) karena status anggota Perhimpunan Indonesia sebagai mahasiswa membawa posisi mereka tanpa ikatan sosial politik tertentu dan tidak memiliki kepentingan untuk mempertahankan kedudukan, sehingga mereka tidak khawatir dalam bertindak terang-terangan melawan pemerintah Belanda. Bertitik tolak dari pemikiran tersebut, ketika angkatan pertama lulusan sekolah dari negeri Belanda pulang ke Hindia Belanda (Indonesia) pada tahun 1923. Mereka mulai ikut organisasi-organisasi yang ada di Indonesia. Hal ini dimaksudkan supaya alumni lulusan sekolah dari Belanda tersebut dapat berkontribusi dalam menyebarkan semangat nasionalisme atau bahkan memperjuangkan kemerdekaan.

Proses ini tidak menunjukkan hasil yang memuaskan. Ada beberapa gagasan yang tidak sepenuhnya dapat diterapkan. Adapun beberapa yang membentuk kelompok-kelompok studi seperti Kelompok Studi Indonesia di Surabaya, Kelompok Studi Umum di Bandung, diikuti kota-kota lain di Jawa dan diluar Jawa, partai-partai politik seperti Perserikatan Nasional Indonesia kemudian menjadi Partai Bangsa Indonesia di Bandung, Partai Bangsa Indonesia di Surabaya, organisasiorganisasi kepanduan seperti Organisasi Kepanduan Nasional Indonesia di Bandung, Persaudaraan antara PanduPandu di Batavia, organisasi-organisasi pemuda seperti Perhimpunan PelajarPelajar Indonesia di Batavia, Pemuda Indonesia di Bandung dan sebagainya (Koesalah dan Soesilo Toer,1993:6). Para tokoh-tokoh ini mencari celah salah satunya membentuk kelompokkelompok studi yang ditujukan untuk mencerdaskan rakyat. Mereka meyakini ini merupakan proses yang akan membentuk mental rakyat apalagi dengan adanya politik etis. Kebijakan ini membuat agak leluasa bagi tokoh alumni Perhimpunan Indonesia seperti Arnold Mononutu, Mr. Sunario, Mr. Moh. Nazief dan Wilopo. Tokoh tokoh ini merupakan orang penting dalam Perhimpunan Indonesia.

Arnold Mononutu mulai menjadi anggota Perhimpunan Indonesia tahun 1923 dan menjadi wakil ketua dalam kepengurusan Soekiman Wirdjosanjoyo (1925-1926). Dalam kedudukannya sebagai wakil ketua Perhimpunan Indonesia, Arnold mewakili kawan- 
kawannya untuk mengikuti kuliah di Akademi Hukum Internasional. Selama menjadi mahasiswa hukum itulah ia memperjuangkan kedudukan tersendiri sebagai mahasiswa Indonesia dalam Perhimpunan Pelajar Akademika Hukum Internasional Den Haag, lepas dari mahasiswa Belanda. Selama itu para mahasiswa Indonesia harus bergabung dengan mahasiswa Belanda karena menjadi koloni dari Belanda. Arnold menolak dan dalam rapat ia menyatakan bahwa bangsa Indonesia dilihat dari sudut nasional mempunyai kepribadian sendiri dan lepas dari kepribadian Belanda.

Selanjutnya Arnold juga meminta mahasiswa Indonesia dipisahkan dan lepas dari kelompok mahasiswa Belanda. Dalam proses ini disepakati dan dianggap sebagai kelompok sendiri. Arnold juga dikenal sebagai diplomat yang cerdas dan menguasai bahasa Perancis sehingga menjadi duta besar tidak resmi Perhimpunan Indonesia di Paris. Dalam kedudukan sebagai duta besar atau perwakilan ia berhasil mengangkat isu nama Indonesia di pentas internasional (Koesalah dan Soesilo Toer, 1990: 11). Dalam perkumpulannya Arnold dan kawankawan menceritakan perjuangan bangsa Indonesia dalam melawan penjajah Belanda. Moh. Hatta juga demikian, sehingga nama Indonesia mulai dikenal oleh dunia internasional.
Setelah itu pada Arnold Mononutu terpaksa pulang sebelum menyelesaikan pendidikannya. la dicap sebagai komunis oleh pemerintahan Hamengkubuwono sehingga uang subsidi dari pemerintah yang diberikan kepadanya dihentikan. Belum lagi ia mendapat ancaman langsung dari pemerintah yang membuatnya harus pulang ke tanah air. Setelah sampai di tanah air, Arnold Mononutu bekerja di perusahaan milik Jepang dan mendapatkan gaji sebesar 400 Gulden.

Tokoh Moh. Nazief merupakan anggota Perhimpunan Indonesia. Dalam kepengurusan Datoek Pamoentjak tahun 1924-1925 Moh. Nazief menjadi archivaris atau penanggungjawab arsip dan pada kepengurusan selanjutnya tahun 1925-1926 Moh. Nazief menjadi bendahara II, sedangkan bendahara I dijabat oleh Moh. Hatta. Nazief merupakan mahasiswa hukum di negeri Belanda. Bersama Ahmad Soebardjo dan Moh. Hatta ia mengisi majalah Indonesia Merdeka yang ditebitkan oleh Perhimpunan Indonesia dengan redaktur Moh. Hatta, Ahmad Soebardjo dan Darmawan Mangunkoesoemo. Sebagai mahasiswa hukum mereka menulis artikel-artikel yang mengecam politik dan kebijakan pemerintah Belanda. Dampaknya mereka dijadikan sasaran penangkapan pemerintahnya Belanda. Pada bulan September 1927 Moh. Hatta, Nazir Datoek, Abdoelmadjid 
Djojoadiningrat dan Ali Sastroamodjojo ditangkap, sedangkan Moh. Nazief memutuskan untuk pulang ke tanah air dan tidak kembali lagi ke Belanda (Koesalah dan Soesilo Toer, 1990:39). Mr. Sunario adalah tokoh penting juga dalam Perhimpunan Indonesia. Mr. Sunario di Belanda hanya dalam dua tahun terhitung mulai Februari 1924 sampai Juni 1926. Dalam waktu singkat itu banyak hal yang telah dilakukannya. la berhasil menyelesaikan studi dengan meraih gelar meester in de rechten (ahli hukum) dari Universitas Leiden dan sempat menjadi sekretaris II dalam kepungurusan Soekiman Wirdjosanjoyo. Mr. Sunario adalah tokoh yang berani dan cerdas. Dalam rapat Perhimpunan Indonesia pada tanggal 7-28 Maret 1926 untuk membahas bentuk konstitusi yang dicita-citakan untuk kemerdekaan bangsa di massa depan. Sunario mengusulkan bentuk negara kesatuan, akan tetapi sebagian besar mengusulkan dalam bentuk serikat, alasannya adalah bahwa masyarakat Indonesia adalah gabungan antara budaya dan adat serta tersebar banyak pulau-pulau.

Dalam masa dua tahun sebelum akhirnya ikut mendirikan Perguruan Rakyat, Sunario aktif dalam melakukuan kegiatan dalam perjuangan kebangsaan. Antara lain sebagai berikut.

1. Memimpin gerakan kepanduan NPO (Nationale Padvinders Organistie atau Organisasi Pandu Nasional) di
Bandung tahun 1926, dimana ia mewajibkan kepada para pemandu untuk mengenakan dasi merahputih, lambang bangsa Indonesia (dengan kepala kerbau di tengah) yang sejak 1923 dipakai Perhimpunan Indonesia di Belanda.

2. Bersama Ir. Soekarno, Mr. Sartono, Mr. Boediarto, Dr. Samsi di Bandung pada tahun 1927 mendorong para mahasiswa THS (Technische Hogeschool atau Sekolah Tinggi Teknik) untuk mendirikan organisasi pemuda pertama kali tidak berorientasi kepada sifat kedaerahaan, yaitu Jong Indonesia yang kemudian dalam konggresnya pad bulan Desember 1927 berubah nama menjadi Pemuda Indonesia, bahkan menetapkan bahasa Indonesia sebagai bahasa pengantar (voertaal). Bagian dari organisasi ini bergabung dengan NPO menjadi INPO (Indonesisch Nationale Padvinders Organisatie atau Organisasi Pandu Nasional Indonesia) yang dipimpin oleh Sunario.

3. Bersama dengan Ir. Soekarno, Ir. Anwari, Mr. Iskaq Tjokroadisoerjo, Mr. Boediarto, Dr. Samsi, Soedjadi dan J. Tilaar mendirikan PNI (Perserikatan Nasional Indonesia) kemudian mengubah nama menjadi Partai Nasional Indonesia di Bandung, 4 Juli 1927. 
4. Ikut mendirikan Taman Madya, Taman Siswa cabang Bandung bersama Drs. Sosrokartono, Dr. Sastrowidagdo, Ir. Soekarno, 6 Juli 1927.

5. Menjadi salah seorang penting dalam kelompok pemikir yang mendorong penyelenggaraan Konggres Pemuda II di Jakarta, 27-28 Oktober 1928 dengan anggota kelompok lain Moh. Nazief, Arnold Mononutu, Mr. Sartono, Amir Sjarifoeddin, Soenarko, Moh. Jamin dan Abdoellah Sigit. la pun menjadi peserta konggres tersebut dan ikut mencetuskan sumpah pemuda dan berusaha untuk mengamalkannya (Koesalah dan Soesilo Toer, 1993:38).

Untuk dapat mempersatukan kekuatan bangsa yang selama ini merupakan menjadi penghambat atau penghalang bersama maka perlu dibentuk kekuatan dalam rangka pembentukan suatu pemerintahan yang bertanggungjawab kepada rakyat dan juga diadakan Konggres Pemuda Indonesia ke II. Konggres ini berlangsung pada 30 April sampai 2 Mei 1926. Dan setelah itu diselenggarakan lagi Konggres Pemuda Indonesia tanggal 27 sampai 28 Oktober 1928 yang menghasilkan Sumpah Pemuda dan pembentukan Permufakatan Perhimpunan Politik Kebangsaan Indonesia (PPPKI) pada tahun 1928.
Organisasi ini juga membuat lambang untuk Indonesia diantaranya merah putih sebagai bendera. Semenjak berakhirnya Perang Dunia I perasaan anti kolonialis dan imperialis di kalangan pimpinan dan anggota Perhimpunan Indonesia semakin menonjol, apalagi setelah ada seruan dari Presiden Amerika Serikat, Woodrow Wilson mengenai hak untuk menetukan nasib bangsa sendiri. Tahun 1925 Perhimpuanan Indonesia semakin tegas memasuki kancah politik, yang juga didorong juga oleh kebangkitan nasionalisme di Asia-Afrika.

Disamping itu, mengusahakan suatu pemerintahan untuk Indonesia, yang bertanggung jawab kepada rakyat Indonesia semata-mata, dan hal yang demikian itu hanya bisa dicapai oleh rakyat Indonesia sendiri tanpa mengharapkan bantuan siapapun dan pada prinsipnya menghindarkan perpecahan demi tercapainya tujuan. Dengan pemikiran yang demikan, maka wajar apabila Perhimpunan Indonesia menjadi satu ancaman terhadap kredibilitas pemerintah Belanda dalam menjalankan kolonialismenya di Indonesia. Hal itu membuat Belanda mengalami kekhawatiran.

Ketiga tokoh itu yang mempunyai pengaruh besar terhadap berdirinya Perguruan Rakyat di Jakarta. Mereka ingin menuangkan apa yang didapat dari negeri Belanda ke dalam sebuah 
pendidikan yang kemudian menjadi pelopor bagi tokoh-tokoh yang lain untuk bergabung dan ikut membesarkan Perguruan Rakyat. Mereka sadar politik etis sebagai aling-aling mereka dari ancaman pemerintah Belanda untuk mengembangkan kegiatannya dalam pendidikan. Langkah dari kesadaran kolektif dalam pembentukan sebuah lembaga pendidikan merupakan kreativitas dan inisiatif yang muncul dari kalangan intelektual yang diyakini dapat merubah kehidupan rakyatnya.

Sejarah pergerakan Indonesia pada masa awal tahun 1900-an mempunyai ciri khas, yakni mempergunakan media pers, bidang pendidikan atau perguruan dan bidang olahraga (Subagyo Toer, 1990: 25). Ciri ini mulai muncul sekitar tahun 1920-an. Yayasan Perguruan Rakyat didirikan mempunyai alasan yang cukup kuat. Dengan adanya kebijakan politik etis dan adanya pergerakan tokoh-tokoh politik yang menjadikan pendidikan sebagai sarana untuk menyebarkan nilai-nilai nasionalisme menjadi langkah yang strategis pada waktu itu. Selain itu juga sebagai aplikasi dari Sumpah Pemuda dan nilainilai dari para alumni Perhimpunan Indonesia melalui pendidikan.

Sumpah Pemuda merupakan manifestasi kesadaran kolektif yang terwujud sebagai solidaritas yang mengarah pada satu tujuan. Bentuk solidaritas itu bukan hanya ikatan komunal seperti yang lazim dijumpai, melainkan solidaritas yang berdasar pada kepentingan bersama. Yayasan Perguruan Rakyat bermula pada sebuah kegiatan rutinitas berupa ceramahceramah. Ceramah-ceramah ini diadakan dengan tujuan untuk meningkatkan wawasan masyarakat, terutama para pemuda.

Kegiatan ceramah ini dilaksanakan di Jakarta dan dibersamai oleh tokohtokoh alumni Perhimpunan Indonesia. Setelah sepulang dari Belanda dan mendapatkan ilmu Mr. Sunario bersama Arnold Mononutu ingin sekali berbagi pengalaman dengan masyarakat Indonesia. Mr. Sunario, Arnold Mononutu dan dibantu teman sejawat mereka bergantian memberikan wawasan terutama terkait masalah kebangsaan, nasionalisme kemerdekaan dan kondisi bangsa pada masa itu. Kegiatan ini berjalan dengan sembunyi-sembunyi supaya tidak diketahui oleh Belanda.

Ceramah ini diselenggarakan secara rutin akan tetapi juga melihat situasi dan kondisi juga. Apabila situasi dan kondisi tidak memungkinkan maka kegiatan ceramah tidak dilaksanakan, misalnya ada kendala dari pembicara atau ada kondisi politik yang memanas atau tidak aman. Ceramah biasanya dilaksanakan pada sore hari dan malam hari, sehingga sering disebut sekolah sore. Mr. Sunario dan Armold Mononutu sadar perlunya sebuah terobosan supaya 
kegiatan yang mereka lakukan mendapat toleransi dari Belanda. Akhirnya mereka menggandeng sebuah pusat bacaan yang bernama Pustaka Kita. Pustaka Kita merupakan perpustakaan tempat pusat bacaan yang memiliki sejumlah koleksi buku sejarah dan berbagai macam surat-surat kabar.

Para kaum intelektual banyak berkumpul disini dan dalam perkumpulan kecil ini sering terjadi diskusi dan ceramah-ceramah. Pengurus dari perpustakaan ini juga mempunyai satu tujuan yaitu berusaha membangun menjadi sebuah perpustakaan dan mengadakan kegiatan ceramah-ceramah untuk memberikan pendidikan kepada rakyat dalam rangka persatuan dan kesatuan. Tidak lama kemudian lembaga yang bernama Persatuan untuk Belajar ikut bergabung. Persatuan untuk Belajar merupakan perkumpulan dari beberapa pengajar bahasa asing. Para pengajar tersebut membuka kursus dalam satu wadah yang disebut Persatuan untuk Belajar. Kursus yang dibuka adalah bahasa Inggris, bahasa Jerman, bahasa Prancis, dan jurnalistik. Persatuan untuk Belajar didirikan oleh 19 orang tokoh diantaranya adalah Angron Soedirdjo, Drs. Soediro dan kakak R.A Kartini yang ikut membantu dalam proses pengajaran.

Sebelumnya penggabungan terjadi komunikasi dengan pihak dari Mr. Sunario, pihak Persatuan untuk Belajar untuk membicarakan masa depan dan tujuan yang dimaksud. Pada waktu itu koordinasi dipimpin oleh Sardjono. Sardjono adalah tokoh yang mempunyai simpati besar dalam bidang pendidikan. Rapat berlangsung di ruang pavilyun gedung sekolah Muhammadiyah di jalan Kramat no. 49, Jakarta. Dalam rapat itu disepakati adanya penggabungan usaha pendidikan. Tanggal 30 Agustus 1928 disepakati bersama nama usaha ini yaitu Volskuniversiteit.

Setelah sumpah pemuda Mohammad Yamin mengusulkan agar nama Volskuniversiteit dibahasakan Indonesia yaitu menjadi Perguruan Rakyat. Mohammad Yamin ingin mengurangi istilah-istilah Belanda dan ingin melestarikan bahasa Indonesia. Pada tanggal 11 Desember 1928 maka resmi didirikan Badan Persatuan Perguruan Rakyat. Mr. Dr. Moh. Nazief dipercaya untuk menjadi Ketua Badan Persatuan Perguruan Rakyat. Mr. Sunario menjadi wakil Ketua, sekretaris I dan II dipercayakan kepada Arnold Mononutu dan Soedarmo Atmodjo, Bendahara I dan II diemban oleh B. Tomowardjojo serta Sanoesi Martadisastra. Njonoprawoto menjadi komisaris dalam kepengurusan tersebut. Selain itu juga dibantu oleh anggota yang terdiri dari Dr. Asikin Widjajakoesoe, Mr. Moh Yamin, dan Soenarko. 
Tepat 44 hari yaitu tanggal 11 Desember 1928 setelah sumpah pemuda Perguruan Rakyat didirikan di Jakarta. Dalam peresmian tersebut dihadiri pula para pemuda-pemuda yang ikut melakukan kegiatan sumpah pemuda. Ini merupakan sekolah pertama yang dengan jelas dan tegas didirikan atas dasar pemikiran Sumpah Pemuda dan atas pola pemikiran Indonesia. Perguruan Rakyat tidak bersifat lokal, regional ataupun keagamaan seperti sekolah lainnya. Sekolah ini mempunyai konsep kebangsaan yang menjadi dasar atau landasan pemikiran sekaligus pembeda dengan sekolah-sekolah lainnya.

Sekolah ini berdiri secara formal dan diketahui oleh pemerintah Belanda. Hal ini sudah sejalan dengan politik etis yang diterapkan oleh Belanda. Kedudukan Yayasan Perguruan Rakyat semakin kuat karena didukung Husni Thamrin. Husni Thamrin pada waktu itu menjadi anggota Dewan yang mempunyai pengaruh pada pemerintah Belanda (wawancara Soesilo Toer, 2015). Husni Thamrin merupakan tokoh yang pertama memberi lahan tanah kepada Perguruan Rakyat untuk mendirikan sekolah. Bukan hanya itu beberapa tokoh seperti Soekarno, Abdul Gani, Latief Hendraningrat, Mr. Sumanang, Amir Syarifudin, Mr. Sunario dan beberapa tokoh Sumpah Pemuda mendukung berdirinya sekolah ini.
Mereka adalah orang-orang politik yang bersembunyi dalam pendidikan.

Sekolah ini sudah formal terbentuk dan segera melaksanakan kegiatannya dalam pendidikan. Letak gedung tempat belajar semula ada di Gang Kenari (wawancara Soesilo Toer, 2015), yaitu suatu gedung milik Mohammad Husni Thamrin yang sengaja untuk menampung kegiatan pendidikan. Pada waktu itu sulit untuk mendapatkan ruangan untuk mengadakan rapat umum, sehingga sering menggunakan ruangan bioskop. Supaya lembaga ini berjalan sehat dan terarah maka dibentuk pula badan pengawas untuk mengawasi berjalannya lembaga tersebut. Badan pengawas diketuai oleh R.M Koesomo Soebrata, sekretaris dipegang oleh Koesoema Soebrata dan anggotanya terdiri dari Mr. Hardi, Dahlan Abdoellah, Mr. Sartono, Dr. Kajadoe, Moeh. Hoesni Thamrin.

Kurikulum yang dipakai sama dengan sekolah yang diterapkan oleh pemerintah. Pelajaran pelajaran tentang pengetahuan umum sama saja dengan buku yang ada di buku-buku pemerintah. Kalau ada latar belakang pemikiran menurut pandangan kita tidak benar, maka diadakan perubahan yang diambil dari masyarakat, sehingga banyak buku-buku pandangan pemerintah yang kita ganti dengan pandangan kita sendiri menurut kenyataan di masyarakat. Menurut 
(Wilopo,1978: 6) pengkajian keadaan yang sebenarnya dengan berdiri di atas kesejahteraan rakyat mengesampingkan dalil-dalil dalam kebijaksanaan pemerintah kolonial yang merugikan adalah ciri khas Perguruan Rakyat. Bisa diambil kesimpulan bahwa Perguruan Rakyat berorientasi pada masyarakat bukan pada pemerintah kolonial. Pada 10 Januari 1972 Pemerintah mengeluarkan Surat Keputusan Gubernur Kepala Daerah Khusus Ibukota Jakarta yang pada waktu itu dikeluarkan Ali Sadikin menyatakan bahwa sekolah yang bersifat nasional pertama di Indonesia adalah Perguruan Rakyat. Hal ini menjadi bukti nyata bahwa sekolah ini mempunyai sejarah dan kontribusi yang besar untuk kemajuan pendidikan di Indonesia.

\section{PENUTUP}

\section{Kesimpulan}

Perguruan Rakyat merupakan sekolah dalam konsep kebangsaan. Hal ini dapat dilihat dalam sendi-sendi atau dasardasar Perguruan Rakyat dan sistem pengajaran yang diterapkan. Perguruan Rakyat didirikan atas dasar aplikasi dari Sumpah Pemuda dan dampak dari kebijakan politik etis. Munculnya nasionalisme merupakan sebagai acuan untuk memberikan pengertian ini kepada rakyat. Pendidikan adalah cara yang tepat untuk memberikan wawasan nasionalisme dan kebangsaan kepada rakyat. Tokoh-tokoh pendiri berasal dari beberapa alumni Perhimpunan Indonesia.

\section{DAFTAR PUSTAKA}

Hussin Dkk. (1976). Pendidikan di Indonesia 1900-1974. Jakarta: PN Balai Pustaka.

Koesalah Soebagyo Toer. (1990). Perguruan Rakyat. Jakarta: Litbang Yayasan Perguruan Rakyat.

Koesalah dan Soesilo Toer. (1991). Perguruan Rakyat 11 Desember 1928. Jakarta: Litbang Yayasan Perguruan Rakyat.

Koesalah \& Soesilo Toer. (1990). Perguruan Rakyat Sekolah Nasional Pertama di Indonesia 11 Desember 1928. Jakarta: Litbang Yayasan Perguruan Rakyat.

Kuntowijoyo. (2005). Pengantar IImu Sejarah. Yogyakarta: Bentang Budaya.

Kuswono, K. (2016). Marhaenism: Social Ideology Create by Sukarno. Historia, 4(2), 119-130.

Sartono Kartodirdjo. (1984). Jurnal Prisma: Pelembangan Politik. Jakarta: LP3ES.

Sartono Kartodirjo. (1993). Pendekatan Ilmu Sosial dalam Metodologi Sejarah. Jakarta: Gramedia.

Suwidi, Tono. (2009). Mahakarya Soekarno-Hatta Tonggak Pemikiran Bapak Bangsa. Jakarta: P.T. Perspektif Media Komunika.

\section{Sumber Lisan (Wawancara)}

Bapak Soesilo Toer (Pegawai Lit Litbang Pengurus Perguruan Rakyat tahun 1991-2003).

Bapak Jabril (Ketua Yayasan Perguruan Rakyat). Beliau masih aktif dan sekarang yang mengelola Yayasa Perguruan Rakyat. 
Sejarah Berdirinya Perguruan Rakyat..., Putut Wisnu Kurniawan, 15-32 